\title{
Effect of rain simulation on Xanthomonas oryzae pv. oryzae population density in guttation fluid and on the spread of bacterial blight in rice
}

\author{
R. Kiran ${ }^{1 *}$ and P. P. Singh ${ }^{2}$ \\ Department of Plant pathology, Punjab Agricultural University, Ludhiana-141004, INDIA \\ *Corresponding author. E-mail: paurajkiran@gmail.com
}

Received: October 18, 2014; Revised received: February 15, 2015; Accepted: February 26, 2015

\begin{abstract}
Bacterial blight of rice caused by Xanthomonas oryzae pv. oryzae is most serious biotic constraint of rice production in Punjab, influenced mainly by environmental factors and nutritional factors applied to the rice crop. Present study aimed at observing the relationship between rain simulation and disease spread. More number of bacterial colonies was recovered from the susceptible rice cultivar (Pusa 1121) plants where no-rain was simulated as compared to those where rain was simulated. Mean bacterial log cfu in rain simulated plant was 4.88 as compared to 5.67 in non rain simulated plots after 1 day of inoculation. The population densities of bacteria increased gradually in both the treatments. The log cfu of bacteria was 5.84 in rain simulated plots as compared to 6.28 in non rain simulated plots after 7 days of inoculation. However after 14 days of inoculation, the bacterial population in guttation fluid was found to be non-significant at $5 \%$ level of significance in rain and non rain simulated plots but the bacterial population was found to be less as compared to that after 7 days of inoculation. Rain washed off the guttation fluid which resulted in decrease of bacterial load in the infected leaf. The significant difference at $5 \%$ level of significance was observed between the per cent disease severity and disease spread was also observed in rain simulated plots and no rain simulated plots in cultivar Pusa 1121 which is a bacterial blight resistant cultivar.
\end{abstract}

Keywords: Guttation, log CFU, Pusa 1121, Rain simulation

\section{INTRODUCTION}

Rice (Oryza sativa L.) is one of the most important food crops, widely cultivated world over and is staple food of more than half of the human race (Caicedo et $a l ., 2007)$. One of the major constraints in the Basmati rice production is the loss in grain yield due to the occurrence of a number of diseases of fungal and bacterial origin like blast, sheath blight, bakane, false smut and bacterial blight. Bacterial blight, caused by Xanthomonas oryzae pv. oryzae is serious problem in rice. Bacterial blight is a primarily vascular disease and under humid weather conditions disease occurs in two phases. The first phase i.e. seedling wilt or kresek phase is less common, whereas the second phase i.e. leaf blight is most prevalent resulting from secondary infection. During the leaf blight phase, lesions appear on leaf. The lesions on the leaf blades may extend to the leaf sheath. The lesions enlarge in length and width, and may have wavy margins. It turns to a whitish-straw colour from its initial water-soaked greyish or yellowish hue in 1-2 week. Bacterial ooze may be observed in humid and warm conditions. Leaf blight may occur at all growth stages, but it is common from maximum tillering until maturity. Damage is due to the partial or total blighting of the leaves or due to wilting of tillers leading to unfilled grains. Disease can cause up to 50 per cent yield losses (Gnanamanickam et al., 1999). It is hypothesized that guttation plays an important role in spread of many diseases. Guttation is a physiological phenomenon resulting in oozing of drops of xylem sap on the tips or margins of leaves of some vascular plants. Rice leaves guttate through structures called hydathodes situated along the margins and tips (Singh, 2014). Thus, $X$. oryzae pv. oryzae suspended in the water droplets gain entrance through the hydathodes into the vascular tissues. In addition, the water droplets secreted from hydathodes contain trace amounts of organic and inorganic substances that may serve as chemical attractants as well as nutrient sources for plant pathogenic bacteria (Feng and Kuo, 1975). The rate of guttation has been shown to vary with the crop growth stages. The guttational exudates are a carrier of numerous organic and inorganic constituents and these may be playing a significant role in the multiplication and spread of $X$. oryzae pv.oryzae, pathogen of bacterial blight of rice. It has been shown that rain splash can play a major part in the spread of many fungal and bacterial plant pathogens (Fitt et al., 1989, Bock et al 2012). Therefore, keeping in view the importance of $X$. oryzae pv.oryzae in guttation fluid, an attempt to study the effect of rain on the bacterial population was undertaken.

\section{MATERIALS AND METHODS}

The studies on the effect of rain simulation on the bacterial population in guttation fluid which influenced the development and spread of bacterial blight was conducted in 
Research Farm, Department of Plant Pathology, Punjab Agricultural University, Ludhiana. The study was done by using plate assays and field inoculations in bacterial blight susceptible basmati rice cultivar Pusa 1121 and resistant rice cultivar Punjab mehak-1. Rain simulation was done at tillering stage as the disease incidence observed at tillering was found to be maximum. The rain simulation was done with a knapsack sprayer during morning and evening hour after inoculation. The duration of rain simulation was 15 minutes and it was done up to 4 weeks of inoculation. The simulated rain droplets were kept equally distributed on whole plot.

For measurement of disease severity, the data was recorded periodically i.e. after 2 week and 4 week of inoculation at seedling, tillering and booting stage. Severity of disease in a plot was recorded as percentage of tissue area infected out of total leaf area. Leaves from the marked plants were assessed to obtain average lesion area $(\%)$ for disease severity in each plot. Spread of bacterial blight disease from the inoculated plant was recorded in both the directions (east-west and north- south). For collection of guttation fluid and assessment of $X$. oryzae pv. oryzae in guttation fluid, guttation fluid was gently collected with a micro-pipette from the upper 10 leaves of inoculated rice plant and stored in Eppendorf tubes (Ding et al., 2001). Guttation fluid on leaves of rice plants was collected at an interval of 24 hour, 1 week and 2 week after inoculation. The fluid from individual plants were stored in $1.5 \mathrm{ml}$ Eppendorf tubes kept in ice box. The guttation fluid was used the same day or kept at $-20^{\circ} \mathrm{C}$ for long term storage. The guttation fluid collected from rice leaf was then serially diluted up to $10^{-4}$ dilution. Plating was done for $10^{-3}$ and $10^{-4}$ dilutions and $100 \mu \mathrm{l}$ of each dilution was transferred to Petri plates containing $X$. oryzae pv. oryzae specific media i.e. Wakimoto media. The fluid was evenly spreaded onto the Wakimoto plates using sterile L-spreader (HiMedia Laboratories). The petri plates were then incubated at room temperature $\left(25^{\circ} \mathrm{C}\right)$ for 2 days, the viable colonies were manually counted and number of colony forming unit per $1 \mathrm{ml}$ of guttation fluid was calculated by using the formula: Number of CFUs per $\mathrm{ml}$ of sample $=\{$ Number of CFU/ Volume plated $(\mathrm{ml})\} \times$ total dilution used

The data for bacterial log CFU and disease severity was statistically analyzed using SigmaStat version 11 . The significance of difference was tested at five per cent level of probability.

\section{RESULTS AND DISCUSSION}

Rainfall was simulated to observe its effect on guttation fluid and further disease development and spread at tillering stage in bacterial blight susceptible (Pusa 1121) and resistant (Punjab Mehak-1) cultivar. In the current study, it was observed that rain simulation had an adverse effect on recovery of $X$. oryzae pv. oryzae from rice leaves. More number of bacterial colonies was recovered from the plants where no-rain was simulated as compared to those where rain was simulated. It is evident from table 1 that mean bacterial $\log$ CFU of 4.88 was recovered from the plants where rain was simulated while 5.67 was recovered from non-rain simulated plots in susceptible cultivar after 1day of inoculation. Although population density of bacteria increased gradually at 7 and 14 days interval in both rain-simulated as well as in no rain simulated plot, yet the increase was more in the treatment when no rain-simulation was done. The log CFU of bacteria in rain simulated plots was 5.84 as compared to 6.28 in non rain simulated plots after 7 days of inoculation. The difference between the two was statistically significant at $5 \%$ level of significance at 1 and 7 day of inoculation. However after 14 days of inoculation, the bacterial population in guttation fluid was maintained and did not differ significantly at 5\% level of significance.

Contrary to it, the bacterial populations were not maintained in the resistant cultivar Punjab Mehak-1 and temporal decline was observed with population recovered decreased with increase in time interval. The trend of getting more number of bacterial density in guttation fluid of plant where no rain was simulated was observed even in the resistant rice cultivar up to 7 days of inoculation. The mean $\log$ CFU was 4.14 in rain simulated as compared to 4.80 in no rain simulated plant after 1 day of inoculation, but after 7 days the decrease in density of bacteria in guttation fluid was observed. The mean log CFU substantially decreased to 2.16 in rain simulated as compared to 2.76 in non-rain simulated plots respectively. Further decrease in bacterial population was observed after 14 days of inoculation (Table 1). The difference between the two was statistically significant at $5 \%$ level of significance after 1 day and 7 days of inoculation and no statistical difference was observed after 14 days of inoculation. This data showed that in resistant varieties bacterial growth and multiplication is highly restricted although very low levels of bacterial densities are still recoverable from guttation fluid even after 14 days of inoculation.

The bacterial population present in the guttation fluid directly influenced the severity of bacterial blight on inoculated plants. High disease severity was observed on the inoculated plants in both rain simulated $(21.4 \%)$ and non rain simulated $(23.0 \%)$ plot in susceptible cultivar Pusa 1121(Table 3). On the contrary, disease severity was very less on inoculated plant in resistant cultivar i.e. $1.2 \%$ in rain simulated plant and $2.1 \%$ in non rain simulated plants (Table 2). The significant difference at $5 \%$ level of significance in the population densities of bacteria in guttation fluid can be attributed to the washing down of inoculum load carried in the guttation drops in the morning due to the simulated rainfall. Although, the disease severity on inoculated plants did not differ significantly (Table 1), yet the bacterial load in the guttation fluid dropped significantly. Hence, the simulated rainfall decreased the total number bacterial colonies that were recovered from the guttation fluid in the following morning after 
Table 1. Effect of rain simulation on population density of X. oryzae pv. oryzae in guttation fluid of artificially inoculated susceptible and resistant rice cultivars.

\begin{tabular}{|c|c|c|c|c|c|c|}
\hline \multirow[t]{3}{*}{ Cultivars } & \multicolumn{6}{|c|}{ Population density of $X$. oryzae pv. oryzae $(\log \mathrm{CFU} / \mathrm{ml}$ guttation fluid) } \\
\hline & \multicolumn{3}{|c|}{ Rain simulation } & \multicolumn{3}{|c|}{ No rain simulation } \\
\hline & $\begin{array}{l}1 \text { day after } \\
\text { inoculation }\end{array}$ & $\begin{array}{l}7 \text { days after } \\
\text { inoculation }\end{array}$ & $\begin{array}{l}14 \text { days after } \\
\text { inoculation }\end{array}$ & $\begin{array}{l}1 \text { day after } \\
\text { inoculation }\end{array}$ & $\begin{array}{l}7 \text { days after } \\
\text { inoculation }\end{array}$ & $\begin{array}{l}14 \text { days after } \\
\text { inoculation }\end{array}$ \\
\hline $\begin{array}{l}\text { Pusa } 1121 \\
\text { (Susceptible) }\end{array}$ & $\begin{array}{l}7.6 \times 10^{4} \\
(4.88)^{\mathrm{a}}\end{array}$ & $\begin{array}{l}7.0 \times 10^{5} \\
(5.84)^{b}\end{array}$ & $\begin{array}{l}1.2 \times 10^{6} \\
(6.08)^{c}\end{array}$ & $\begin{array}{l}4.7 \times 10^{5} \\
(5.67)^{d}\end{array}$ & $\begin{array}{l}1.9 \times 10^{6} \\
(6.28)^{\mathrm{e}}\end{array}$ & $\begin{array}{l}1.8 \times 10^{6} \\
(6.26)^{\mathrm{ec}}\end{array}$ \\
\hline $\begin{array}{l}\text { Punjab Mehak- } \\
1 \text { (Resistant) }\end{array}$ & $\begin{array}{c}1.3 \times 10^{4} \\
(4.14)^{\mathrm{a}}\end{array}$ & $\begin{array}{l}1.45 \times 10^{2} \\
(2.16)^{\mathrm{b}}\end{array}$ & $\begin{array}{l}2.0 \times 10^{1} \\
(1.30)^{\mathrm{c}}\end{array}$ & $\begin{array}{c}6.4 \times 10^{4} \\
(4.80)^{\mathrm{d}}\end{array}$ & $\begin{array}{l}5.87 \times 10^{2} \\
(2.76)^{\mathrm{e}}\end{array}$ & $\begin{array}{l}3.5 \times 10^{1} \\
(1.54)^{\mathrm{c}}\end{array}$ \\
\hline \multirow{6}{*}{$\mathrm{P}>\mathrm{F}(0.05)$} & Pusa 1121 & Rain & $<0.001$ & & & \\
\hline & & DAI & $<0.001$ & & & \\
\hline & & Rain $\times$ DAI & $<0.001$ & & & \\
\hline & $\begin{array}{l}\text { Punjab } \\
\text { Mehak-1 }\end{array}$ & Rain & $<0.001$ & & & \\
\hline & & DAI & $<0.001$ & & & \\
\hline & & Rain $\times$ DAI & 0.313 & & & \\
\hline
\end{tabular}

The figures followed by same letter do not differ significantly at $5 \%$ level of significance.

rain simulation. Results of net removal of bacteria from leaf surfaces was also reported by the work of Butterworth and McCartney (1991) in which, they studied the population densities of three species of bacteria viz. Pseudomonas syringae, Klebsiella planticola and Bacillus subtilis on french bean and, Phaseolus vulgaris, oilseed rape and Brassica napus. The artificially infected leaves from these plants were exposed to artificial rain and splash droplets generated by the impact on the leaves were collected on selective nutrient agar in Petri dishes. The bacterial content of the splashed drops showed that rainfall was a very efficient means of removing bacteria from foliar surfaces.

The drop in populations of $X$. oryzae pv. oryzae in resistant cultivars after inoculation have been reported by other workers as well. Mohiuddin and Kauffman (1975) monitored X. oryzae pv. oryzae multiplication in leaves from resistant and susceptible rice cultivars and reported a 100-fold difference between bacterial numbers between compatible and incompatible interactions. In this study also, a 100,000 fold difference between population density of $X$. oryzae pv. oryzae in susceptible and resistant cultivars was observed after 14 days of inoculation.

Pathogenic bacteria have been reported to be present in other xylem inhabiting bacteria also. Sharabani et al. (2012) reported the presence of Clavibacter michiganensis subsp. michiganensis $(\mathrm{Cmm})$ in the guttation fluid of

Table 2. Rain simulation effect on disease severity in rice cultivar Pusa 1121 (on whole plot basis) and rice cultivar Punjab Mehak-1 (on inoculated plant) ${ }^{\#}$ at tillering stage.

\begin{tabular}{|c|c|c|c|c|}
\hline \multirow[t]{3}{*}{ Cultivar } & \multicolumn{4}{|c|}{ Per cent disease severity } \\
\hline & \multicolumn{2}{|c|}{ Rain simulation } & \multicolumn{2}{|c|}{ No rain simulation } \\
\hline & $\begin{array}{c}14 \text { days after } \\
\text { inoculation }\end{array}$ & $\begin{array}{l}28 \text { days after } \\
\text { inoculation }\end{array}$ & $\begin{array}{c}14 \text { days after } \\
\text { inoculation }\end{array}$ & $\begin{array}{l}28 \text { days after } \\
\text { inoculation }\end{array}$ \\
\hline Pusa 1121 (Susceptible) & $5.7^{\mathrm{a}}$ & $11.3^{\mathrm{b}}$ & $5.2^{\mathrm{c}}$ & $12.6^{\mathrm{d}}$ \\
\hline Punjab Mehak-1 (Resistant) & $1.2^{\mathrm{a}}$ & $1.8^{\mathrm{a}}$ & $2.1^{\mathrm{a}}$ & $2.3^{\mathrm{a}}$ \\
\hline $\mathrm{P}>\mathrm{F}(0.05)$ & $\begin{array}{l}\text { Rain } \\
\text { DAI }\end{array}$ & $\begin{array}{r}0.009 \\
<0.001\end{array}$ & & \\
\hline $\mathrm{P}>\mathrm{F}(0.05)$ & $\begin{array}{l}\text { Rain } \\
\text { DAI }\end{array}$ & $\begin{array}{l}0.114 \text { (NS) } \\
0.290(\mathrm{NS})\end{array}$ & & \\
\hline
\end{tabular}

The figures followed by same letter do not differ significantly at $5 \%$ level of significance. \#Per cent disease severity values in cultivar Punjab Mehak-1 is given on the inoculated plant as disease spread was not observed. 
Table 3. Effect of rain simulation on bacterial blight spread from the disease focus in rice cultivar Pusa 1121 at tillering stage after 14 and 28 days of inoculation.

\begin{tabular}{|c|c|c|c|c|c|c|c|c|c|c|c|c|}
\hline & \multicolumn{12}{|c|}{ Per cent disease severity } \\
\hline & \multicolumn{6}{|c|}{$\begin{array}{l}\text { North-South direction } \\
\text { (Distance from infection focus) }\end{array}$} & \multicolumn{6}{|c|}{$\begin{array}{c}\text { East-West direction } \\
\text { (Distance from infection focus) }\end{array}$} \\
\hline & $\mathbf{0}$ & 15 & 30 & 45 & 60 & 75 & $\mathbf{0}$ & 20 & 40 & 60 & 80 & 100 \\
\hline & $\mathbf{c m}$ & $\mathbf{c m}$ & $\mathbf{c m}$ & $\mathbf{c m}$ & $\mathbf{c m}$ & $\mathbf{c m}$ & $\mathbf{c m}$ & $\mathbf{c m}$ & $\mathbf{c m}$ & $\mathbf{c m}$ & cm & $\mathbf{c m}$ \\
\hline & \multicolumn{12}{|c|}{ Rain simulation } \\
\hline 14 days & 21.4 & 9.0 & 2.8 & 1.1 & 0 & 0 & 21.4 & 8.4 & 2.0 & 0.6 & 0 & 0 \\
\hline \multirow{2}{*}{28 days } & 44.3 & 21.3 & 8.4 & 3.2 & 0.7 & 0 & 44.3 & 22.7 & 8.9 & 3.1 & 0.4 & 0 \\
\hline & \multicolumn{12}{|c|}{ No rain simulation } \\
\hline 14 days & 23.0 & 8.0 & 3.7 & 1.3 & 0.2 & 0 & 23.0 & 7.7 & 3.6 & 0.3 & 0 & 0 \\
\hline 28 days & 44.3 & 24.1 & 12.0 & 5.1 & 1.1 & 0 & 44.3 & 22.6 & 12.1 & 4.6 & 1.8 & 0 \\
\hline
\end{tabular}

the source plants. The population densities of $\mathrm{Cmm}$ ranged from $10^{1}$ to $10^{5}$ cells per drop. Similarly, in this study also, $X$. oryzae pv. oryzae populations in the guttation ranged from $7.6 \times 10^{4}$ to $1.8 \times 10^{6}$ in different treatments in susceptible cultivar Pusa 1121.

Stage of the plant at which the infection occurs is also important as reported by Sharabani et al. (2012), who concluded that $\mathrm{Cmm}$ in guttation fluid of seed infected plants was recoverable not till the crop was one month old. However, when pathogen was root inoculated, the $\mathrm{Cmm}$ could be detected in the guttation fluid after one week. In the current study also, pathogenic bacteria were only detected in seedling and tillering stage. No bacteria were recovered from the guttation fluid when the inoculation was done at booting stage.

The effect of rain simulation on disease severity was observed at 14 days and 28 days after inoculation. There was significant difference between the per cent disease severity in rain simulated plots and no rain simulated plots in cultivar Pusa 1121. The disease severity was 5.7 per cent in rain as compared to 5.2 per cent in non rain-simulated plots after 14 days of inoculation (Table 2). This increased to 11.3 per cent in rain simulated plots as compared to 12.6 per cent in no rain simulated plots (Table 2).

The other cultivar i.e. Punjab Mehak-1 possess genetic resistance to Punjab pathotype $\mathrm{PbXo-7}$ of $X$. oryzae $\mathrm{pv}$. oryzae. Therefore, $X$. oryzae pv. oryzae populations could not be maintained and dropped to just 145 and 20 colonies after 7 and 14 days of inoculation respectively (Table 1). The low bacterial populations in the guttation fluid resulted in very less disease severity in inoculated plant. There was no significant difference observed between rain and no rain simulated plants and the disease severity on inoculated plant was noticed to be 1.2 per cent in rain simulated plants as compared to 2.1 per cent in no rain simulated plants after 14 days of inoculation (Table 2).

Watanabe and Asaumi (1975) also conducted an experiment on rapid multiplication of the bacterium in susceptible leaves and observed $10^{6}-10^{7}$ cells of bacterium, when lesion appeared 7-14 days after inoculation. In resistant tissue bacterium multiplied gradually to $10^{5}-10^{6}$ cells without any lesion development. Mew et al. (1984) investigated the establishment of virulent and avirulent $X$. oryzae pv. oryzae strains on the leaf surfaces of resistant and susceptible cultivars. The results suggested that bacteria are immobilized and inhibited from dividing by excretions from water pore in incompatible host-bacteria combinations. So it results in less disease in resistant cultivar.

The bacterial blight spread from the $X$. oryzae pv. oryzae spray inoculated plant (infection focus) to the adjacent plants was recorded in both rain simulated and no rain simulated plot. It is evident from table 3 that spread of bacterial blight had started from infection foci after 14 days of inoculation.

In the current experiments, there was no significant difference in disease spread observed in both rain simulated and no rain simulated plots. In rain simulated plots, the disease spread was noticed up to $45 \mathrm{~cm}$ in north-south direction and $60 \mathrm{~cm}$ in east-west direction from the disease focus. While in non rain simulated plots, spread of disease was up to $60 \mathrm{~cm}$ in North-South direction and up to $60 \mathrm{~cm}$ in east-west direction after 14 days of inoculation.

The data presented in table 3. showed the spread of bacterial blight in rain simulated and non-rain simulated plots after 28 days of inoculation. A further $15-20 \mathrm{~cm}$ of disease spread was noticed at 28 days after inoculation. Here also, disease spread was similar in both rain simulated and non-rain simulated plots. Besides disease spread the disease severity on inoculated and un-inoculated plants also increased. In both rain simulated and non-rain simulated plots, the disease spread was noticed up to $60 \mathrm{~cm}$ in north-south direction and also up to $80 \mathrm{~cm}$ in east-west direction from the disease focus after 28 days of inoculation.

Weather parameters are known to influence disease development and spread of bacterial blight. Mohiuddin et al. (1977) revealed that, with more than 27 rainy days during August, September and October, and with a total rainfall of at least $20 \mathrm{~mm}$, kresek occurs, while leaf blight occurs if the number of rainy days and the amount of rainfall are lower.

Sharma et al. (2007) concluded in his experiment on disease-weather relationships and bacterial blight of rice that there was significant and positive correlation 
observed between bacterial leaf blight severity and rainfall, number of rainy days and minimum relative humidity. Rainfall rate and wind speed were characterized as the most important disease variables in the development of bacterial blight of peas as reported by Roberts (1997) who investigated the effect of weather conditions on simultaneous local (plant to plant) spread and infection of peas with bacterial blight (Pseudomonas syringae pv. pisi) and found that nearly all of the infection events were associated with the occurrence of rain.

\section{Conclusion}

It was concluded that bacterial blight disease severity was more when no rain was simulated as compared to the rice crop simulated with rain. This was proved by the results that rainfall washed off the guttation fluid resulting in decrease of bacterial load in the infected leaf in turn bacterial blight severity. In every experiment, the amount of bacteria recovered was less in rain simulated experiment and more from non rain simulated experiment. The guttation played an important role in disease development as it served as reservoir of bacteria and increased the disease severity.

\section{ACKNOWLEDGEMENT}

Ms. Raj Kiran is highly thankful to Indian Council of Agricultural Research, New Delhi to sanction Junior Research Fellowship to conduct these studies.

\section{REFERENCES}

Butterworth, J. and McCartney, H.A. (1991). The dispersal of bacteria from leaf surfaces by water splash. Journal of Applied Bacteriolology, 71: 484-496.

Bock, C.H., Cook, A.Z., Parker, P.E., Gottwald, T.R. and Graham, J.H. (2012). Short-distance dispersal of splashed bacteria of Xanthomonas citri subsp. citri from canker-infected grapefruit tree canopies in turbulent wind. Plant Pathol, 61: 829-36.

Caicedo, A.L., Williamson, S.H., Hernandez, R.D., Boyko, A., Fledel, A., York, T.L., Polato, N.R., Olsen, KM., Nielson, R., McCouch, S.R., Bastamante, C.D. and Purugganan, M.D. (2007). Genome wide patterns of nucleotide polymorphism in domesticated rice. PLOS Genetics, 3:
1745-1756.

Ding, X.S., Boydston, C.M. and Nelson, R.S. (2001). Presence of Brome mosaic virus in barley guttation fluid and its association with localized cell death response. Phytopathology, 91: 440-448.

Feng, T.Y. and Kuo, T.T. (1975). Chemotactic response of Xanthomonas oryzae toward water droplets collected from water pores on the leaf of rice plants. Botanical Bulletin Academia Sinica, 16: 126-136.

Fitt, B.D.L., McCartney, H.A. and Walklate, P.J. (1989). The role of rain in dispersal of pathogen inoculum. Annual Review of Phytopathology, 27: 241-270.

Gnanamanickam, S.S., Priyadarshini, V.B., Narayanan, N.N., Vasudevan, P. and Kavitha, S. (1999). An overview of bacterial blight disease of rice and strategies for its management. Current Science, 77: 1435- 1443.

Mew, T.W., Mew, I.C. and Haung, J.S. (1984). Scanning of microscopy of virulent and avirulent strains of Xanthomonas campestris pv. campestris on rice leaves. Phytopathology, 74: 635-641.

Mohiuddin, M.S. and Kauffman, H.E. (1975). Multiplication studies of Xanthomonas oryzae isolates on differential rice varieties. Current Science, 44: 637-638.

Mohiuddin, M.S., Verma, J.P. and Rao, Y.P. (1977). Losses due to bacterial blight of rice. Indian Journal of Agricultural Sciences, 47: 221-223.

Roberts, S. J. (1997). Effect of weather conditions on local spread and infection by pea bacterial blight (Pseudomonas syringae pv. pisi). European Journal of Plant Pathology, 103: 711-719.

Singh, S. (2014). Guttation: path, principles and functions. Australian Journal of Botany, 61(7) 497-515.Sharabani, G., Sasson, S.M., Borenstein, M., Shulhani, R., Lofthouse, M., Chalupowicz, L. and Shtienberg, D. (2012). The significance of guttation in the secondary spread of Clavibacter michiganensis subsp. michiganensis in tomato greenhouses. Plant Pathology, 62: 578-586.

Sharma, V.K., Thind, T.S., Singh, P.P., Mohan, C., Arora, J.K. and Raj, P. (2007). Disease-weather relationships and forecasting of bacterial leaf blight of rice. Plant Disease Research, 22: 52-56.

Watanabe, M. and Asaumi, T. (1975). Studies on the physiological changes in the rice plants infected with Xanthomonas oryzae. I. Relationship between the increase in respiratory rate and multiplication of the bacteria in the infected leaves. Annals of Phytopathological Society of Japan, 41: 364-372. 